\title{
Synthesis and Biological Evaluation of Novel Isoxazole-Amide Analogues as Anticancer and Antioxidant Agents
}

\author{
Ahmad M. Eid (D), ${ }^{1}$ Mohammed Hawash ${ }^{D},{ }^{1}$ Johnny Amer, ${ }^{2}$ Abdullah Jarrar, ${ }^{1}$ Samira Qadri, ${ }^{1}$ \\ Iman Alnimer, ${ }^{1}$ Aya Sharaf, ${ }^{1}$ Raya Zalmoot, ${ }^{1}$ Osama Hammoudie, ${ }^{1}$ Saba Hameedi, ${ }^{1}$ \\ and Ahmed Mousa ${ }^{2}$ \\ ${ }^{1}$ Department of Pharmacy, Faculty of Medicine and Health Sciences, An-Najah National University, Nablus P.O. Box 7, \\ 00970 Palestine, State of Palestine \\ ${ }^{2}$ Department of Biomedical Sciences, Physiology, Pharmacology \& Toxicology Division, Faculty of Medicine and Health Sciences, An- \\ Najah National University, Nablus, Palestine, State of Palestine
}

Correspondence should be addressed to Ahmad M. Eid; ahmadeid@najah.edu and Mohammed Hawash; mohawash@najah.edu Received 27 November 2020; Revised 2 February 2021; Accepted 17 February 2021; Published 9 March 2021

Academic Editor: Yanming Xu

Copyright ( $) 2021$ Ahmad M. Eid et al. This is an open access article distributed under the Creative Commons Attribution License, which permits unrestricted use, distribution, and reproduction in any medium, provided the original work is properly cited.

\begin{abstract}
Cancer now is one of the leading causes of mortality in the world. There has been a lot of effort to discover new anticarcinogenic agents that allow treatment with fewer side effects. A series of isoxazole-carboxamide derivatives (2a-2g) were synthesised and evaluated for their cytotoxic activity against breast (MCF-7), cervical (HeLa), and liver (Hep3B) cancer cell lines and their antioxidant activity in the 2,2-diphenyl-1-picrylhydrazyl (DPPH) assay. The results showed that $\mathbf{2} \mathbf{d}$ and $\mathbf{2 e}$ were the most active compounds against $\mathrm{Hep} 3 \mathrm{~B}$ cells, with a half-maximal inhibitory concentration $\left(\mathrm{IC}_{50}\right)$ of around $23 \mu \mathrm{g} / \mathrm{ml}$; $2 \mathrm{~d}$ showed the highest activity against $\mathrm{HeLa}$ cells, with an $\mathrm{IC}_{50} 15.48 \mu \mathrm{g} / \mathrm{ml}$. However, $2 \mathrm{a}$ had the lowest $\mathrm{IC}_{50}(39.80 \mu \mathrm{g} / \mathrm{ml})$ against MCF-7 cells. By contrast, compound $2 \mathrm{~g}$ was inactive against all cancer cell lines, with $\mathrm{IC}_{50}$ values $>400 \mu \mathrm{g} / \mathrm{ml}$. Both $2 \mathrm{~d}$ and $2 \mathrm{e}$ reduced Hep3B secretion of alpha-fetoprotein (to $1829.33 \pm 65.91 \mathrm{ng} / \mathrm{ml}$ and $1758.66 \pm 54.04 \mathrm{ng} / \mathrm{ml}$, respectively). Furthermore, in cell cycle analysis, $\mathbf{2 d}$ and $2 \mathrm{e}$ induced a delay in the G2/M phase of $18.07 \%$, which is similar to the doxorubicin positive control. Moreover, 2d and 2e reduced the necrosis rate of Hep3B threefold and instead shifted the cells to apoptosis. Our results indicate that $\mathbf{2 d}$ and $\mathbf{2 e}$ have potent and promising anticancer activity. However, compound $\mathbf{2 a}$ was the most active as antioxidant agent $\left(\mathrm{IC}_{50}=7.8 \pm 1.21 \mu \mathrm{g} / \mathrm{ml}\right)$ compared with Trolox as a positive control $\left(\mathrm{IC}_{50} 2.75 \mu \mathrm{g} / \mathrm{ml}\right)$.
\end{abstract}

\section{Introduction}

Cancer is the leading cause of death throughout the world [1$3]$. Indeed, $25 \%$ of the deaths in developing countries are due to cancer [4-6]. In 2018, cancer was responsible for 9.6 million deaths. During a person's life, 1 out of 5 men and 1 out of 6 women will develop cancer [7]. Environmental factors such as diet, obesity, alcohol consumption, physical inactivity, radiation, sunlight, and viral infection as well as genetic factors lead to the development of cancer [8]. Over the years, scientists have explored a myriad of treatments for each type of can- cer, including chemotherapy, hormonal treatment, radiation, and surgery [9].

Chemotherapy has been widely used, particularly against inoperable cancer [10], as the primary therapy or as an adjunct therapy before and/or after another treatment [11]. However, chemotherapy use is restricted because it has weak effectiveness, minimal selectivity against target cells, and undesirable side effects such as alopecia, queasiness, and vomiting $[12,13]$. Many natural extracts with anticancer activity have been evaluated in recent decades [14]. One of these compounds, combretastatin (Figure 1), was isolated 


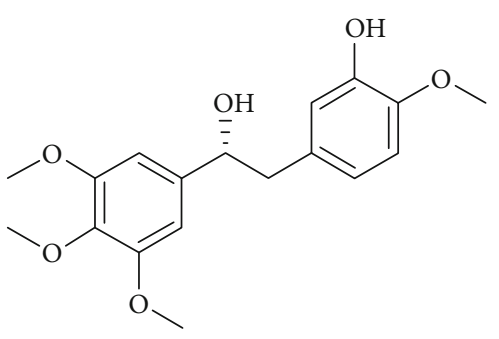

Combretastatin

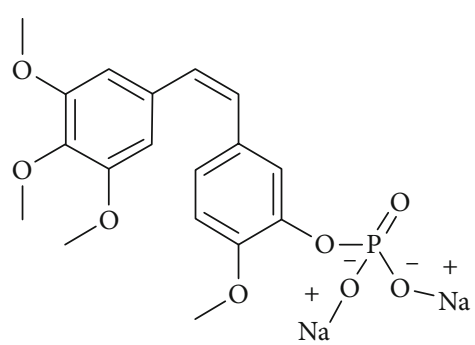

Fosbretabulin<smiles>COc1ccc(CCc2cc(OC)c(OC)c(OC)c2)cc1O</smiles>

CA- 4

Figure 1: Combretastatin, CA-4P (fosbretabulin), and CA-4 structures.

from the African plant Combretum caffrum and has been modified to find new derivatives with antitumour activity, such as combretastatin A-4 phosphate (fosbretabulin) (Figure 1). That compound has been approved by the Food and Drug Administration (FDA) for thyroid cancer [15-17].

Different types of heterocyclic derivatives such as isoxazole are used extensively as agrochemicals in medicine; indeed, they are efficient in anticancer chemotherapy [15, 18]. Researchers have found that the isoxazole ring imparts it with anticancer $[19,20]$, hypoglycemic [21], pain killing, bactericidal [20, 22], antiviral (for HIV) [23], and antiinflammatory [24] activities. The isoxazole ring has been used as a core structure for many anticancer medications [25]. For example, resorcinylic 4,5-diarylisoxazole amides have shown a potent inhibitory effect on heat shock protein (HSP90) [26]. A derivative of diarylisoxazole (Figure 2, st. 1) was discovered for its activity against androgen receptor(AR-) expressing breast cancer cells [27]. Leflunomide, an immunosuppressant used in chemotherapy, is another isoxazole derivative. Other researchers reported that the 3,5dimethylisoxazole (Figure 2, st. 2) functional group mimics acetylated lysine (KAc); they utilised this functional group to improve bromodomain inhibitors, with positive effects on cancer cells [28]. In another work, researchers tested a hybrid molecule, with a trimethoxyphenyl moiety combined with the isoxazole ring (arylamino-isoxazolyl-2-propenone; Figure 2, st. 3). The compound showed cytotoxic activity (low half-maximal inhibitory concentration $\left(\mathrm{IC}_{50}\right)$ values) against several cancer cell lines: cervical adenocarcinoma (HeLa), lung adenocarcinoma (A549), breast carcinoma (MCF7), and hepatocellular carcinoma (HCT116) [29].

Oxidants are formed as a normal product of aerobic metabolism, but they can be produced at elevated rates under pathophysiological conditions. Thus, an imbalance between oxidants and antioxidants in favour of oxidants potentially leads to damage that forms the core of oxidative stress. The biologically active agents that work to slow or prevent the cell damage caused by those free radicals are called antioxidants $[30,31]$. Environmental stress is usually the primary impetus for the formation of these unstable free radicals. While the human body produces endogenous antioxidants, other agents are found in natural plants and foods; examples include $\beta$-carotene, $\mathrm{R}$-tocopherol (vitamin $\mathrm{E}$ ), and ascorbic acid (vitamin C). Other antioxidants can be chemically synthesised [30-33]. In the last few decades, researchers have synthesised many agents that have marked antioxidant activ- ity, such as quinolinone-3-aminoamide [31], thienopyrimidine, thienopyrazole [34], and $N$-aryl-1,4-dihydropyridine derivatives [35]. These substances, like Trolox, a watersoluble vitamin E analogue, and rebamipide (Figure 2), exhibit effective antioxidant properties by scavenging unstable free radicals [31, 36, 37].

The current project is aimed at synthesising novel isoxazole-carboxamide derivatives $(\mathbf{2 a - 2 g})$ with or without a methoxyphenyl moiety and at evaluating some of their biological activity such as antioxidant and anticancer activities on HeLa, MCF-7, HepG2, and HepB3 cancer cell lines.

\section{Materials and Methods}

2.1. Chemistry. All chemicals were obtained from Alfa Aesar and Sigma-Aldrich. SMP-II Digital Melting Point Appliances are used to determined melting points and are uncorrected. ${ }^{13} \mathrm{C}-\mathrm{NMR}$ and ${ }^{1} \mathrm{H}-\mathrm{NMR}$ spectra were recorded in DMSO$\mathrm{d} 6$ and were performed on two NMR instruments. The first was a Bruker 500J MHz-Avance III High-Performance Digital FT-NMR spectrometer at the Faculty of Science, Department of Chemistry, the University of Jordan, Jordan. The second was a Bruker $300 \mathrm{MHz}$-Avance III HighPerformance Digital FT-NMR spectrometer at the NMR facility at the Doping and Narcotics Analysis Laboratory of the Faculty of Pharmacy, Anadolu University, Turkey. Tetramethylsilane was used as the internal standard. All chemical shifts were recorded as d (ppm). High-resolution mass spectra data (HRMS) were collected using a Waters LCT Premier XE Mass Spectrometer (high sensitivity orthogonal acceleration time-of-flight instrument) using the ESI (+) method (the instrument was coupled to an AQUITY Ultra Performance Liquid Chromatography system (Waters Corporation, Milford, MA, USA)) at Pharmacy Faculty, Gazi University, Ankara, Turkey.

2.1.1. General Procedure of Isoxazole-Carboxamide Synthesis (2a-2g). 3-(2-Chlorophenyl)-5-methylisoxazole-4-carboxylic acid (1) (1.5 mmol) was dissolved in dichloromethane $(12 \mathrm{ml})$. To this mixture DMAP $(0.3 \mathrm{mmol}), \mathrm{EDC}(1.8 \mathrm{mmol})$ were added and was allowed to stir under nitrogen gas at room temperature for $30 \mathrm{~min}$. After that, the appropriate aniline derivative $(1.8 \mathrm{mmol})$ was added and the mixture was allowed to stir for $24-48 \mathrm{~h}$. The reaction was monitored by TLC, and at the end of the reaction, the solvent was removed under reduced pressure and dissolved again in 


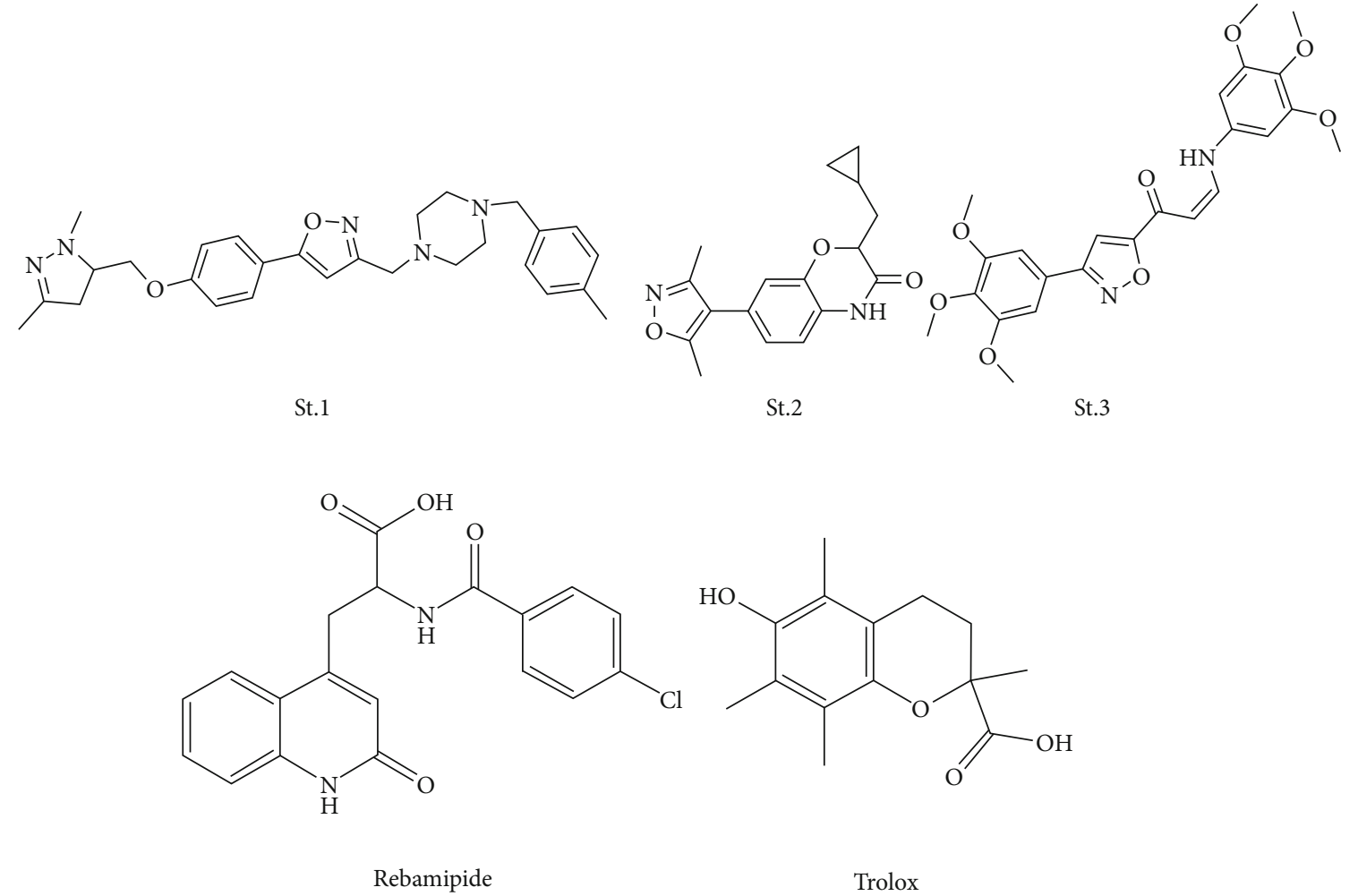

FIgURE 2: Isoxazole containing compounds with anticancer activities, and antioxidant agents (Rebamipide and Trolox).

dichloromethane, then extracted with $1 \% \mathrm{NaHCO}_{3}$ and brine. The organic layer was dried by drying agent $\mathrm{Na}_{2} \mathrm{SO}_{4}$ and evaporated under reduced pressure. The obtained product was purified by flash chromatography using the appropriate solvent system or by the crystallization utilising appropriate solvent system [38].

2.1.2. N-(4-(tert-butyl)phenyl)-3-(2-chlorophenyl)-5methylisoxazole-4-carboxamide (2a). Silica gel column was purified by chromatography using n-hexane: ethyl acetate solvent system $(70: 30)$; solid product, M.P. $175-176^{\circ} \mathrm{C}$, yield $77 \%$; ${ }^{1} \mathrm{H}$ NMR (DMSO-d6) $\delta$ : $10.02(1 \mathrm{H}, \mathrm{s}), 7.43-$ $7.58(6 \mathrm{H}, \mathrm{m}), 7.31(2 \mathrm{H}, \mathrm{d}, J=8.6 \mathrm{~Hz}), 2.65(3 \mathrm{H}, \mathrm{s})$, and $1.24(9 \mathrm{H}, \mathrm{s}) ;{ }^{13} \mathrm{C}$ NMR (DMSO-d $\left.\mathrm{d}_{6}\right) \delta$ ppm: 169.98, 160.40, $159.71,146.74,136.57,132.84,132.24,131.97,130.09$, $127.98,127.79,125.78,120.04,115.13,34.50,31.54,12.73$. HRMS $(m / z):[\mathrm{M}+\mathrm{H}]^{+}$calcd for $\mathrm{C}_{21} \mathrm{H}_{22} \mathrm{ClN}_{2} \mathrm{O}_{2}$ 369.1356, found 369.1364 .

2.1.3. N-(4-chloro-2,5-dimethoxyphenyl)-3-(2-chlorophenyl)5-methylisoxazole-4-carboxamide (2b). Purified by silica gel column chromatography using n-hexane: ethyl acetate solvent system $(70: 30)$; solid product, M.P. $115-117^{\circ} \mathrm{C}$, yield $67 \%$; ${ }^{1} \mathrm{H}$ NMR (DMSO-d $\left.{ }_{6}\right) \delta: 8.83(1 \mathrm{H}, \mathrm{s}), 8.02(1 \mathrm{H}, \mathrm{s})$, 7.55-7.74 $(4 \mathrm{H}, \mathrm{m}), 7.07(1 \mathrm{H}, \mathrm{s}), 3.75(3 \mathrm{H}, \mathrm{s}), 3.52(3 \mathrm{H}, \mathrm{s})$, and $2.75(3 \mathrm{H}, \mathrm{s})$; HRMS $(\mathrm{m} / \mathrm{z}):[\mathrm{M}+\mathrm{H}]^{+}$calcd for $\mathrm{C}_{19} \mathrm{H}_{17} \mathrm{Cl}_{2} \mathrm{~N}_{2} \mathrm{O}_{4} 407.0565$, found 407.0558.

2.1.4. 3-(2-chlorophenyl)-N-(3,5-dimethoxyphenyl)-5methylisoxazole-4-carboxamide (2c). Purified by silica gel column chromatography using n-hexane: ethyl acetate solvent system $(65: 35)$; solid product, M.P. $255-257^{\circ} \mathrm{C}$, yield 82\%; ${ }^{1} \mathrm{H}$ NMR (DMSO-d $\left.{ }_{6}\right) \delta: 9.99(1 \mathrm{H}, \mathrm{s}), 7.45-7.59(4 \mathrm{H}$, m), $7.24(1 \mathrm{H}, \mathrm{d}, J=2.1 \mathrm{~Hz}), 7.02(1 \mathrm{H}, \mathrm{dd}, J=8.7,2.1 \mathrm{~Hz})$, $6.87(1 \mathrm{H}, \mathrm{d}, J=8.7 \mathrm{~Hz}), 3.70(3 \mathrm{H}, \mathrm{s}), 3.69(3 \mathrm{H}, \mathrm{s})$, and 2.65 $(3 \mathrm{H}, \mathrm{s}) ;{ }^{13} \mathrm{C}$ NMR (DMSO-d 6 ) $\delta \mathrm{ppm}: 169.89,160.44$, $159.45,148.94,145.76,132.83,132.70,132.23,131.99$, $130.11,127.99,127.82,112.41,112.19,105.26,56.19,55.81$, and 12.79; HRMS $(\mathrm{m} / z)$ : $[\mathrm{M}+\mathrm{H}]^{+}$calcd for $\mathrm{C}_{19} \mathrm{H}_{18} \mathrm{ClN}_{2} \mathrm{O}_{4}$ 373.0955, found 373.0951 .

2.1.5. 3-(2-Chlorophenyl)-N-(3,4-dimethoxyphenyl)-5methylisoxazole-4-carboxamide (2d). Purified by silica gel column chromatography using n-hexane: ethyl acetate solvent system $(75: 25)$; solid product, M.P. $199-200.5^{\circ} \mathrm{C}$, yield 90\%; ${ }^{1} \mathrm{H}$ NMR (DMSO-d $\left.{ }_{6}\right)$ 8: $9.99(1 \mathrm{H}, \mathrm{s}), 7.47-7.59(4 \mathrm{H}$, m), $7.23(1 \mathrm{H}, \mathrm{d}, J=2.1 \mathrm{~Hz}), 7.02(1 \mathrm{H}, \mathrm{dd}, J=8.4,2.1 \mathrm{~Hz})$, $6.87(1 \mathrm{H}, \mathrm{d}, J=8.7 \mathrm{~Hz}), 3.70(3 \mathrm{H}, \mathrm{s}), 3.68(3 \mathrm{H}, \mathrm{s})$, and 2.65 $(3 \mathrm{H}, \mathrm{s})$; HRMS $(\mathrm{m} / z)$ : $[\mathrm{M}+\mathrm{H}]^{+}$calcd for $\mathrm{C}_{19} \mathrm{H}_{18} \mathrm{ClN}_{2} \mathrm{O}_{4}$ 373.0955, found 373.0948 .

2.1.6. 3-(2-Chlorophenyl)-N-(2,5-dimethoxyphenyl)-5methylisoxazole-4-carboxamide (2e). Purified by silica gel column chromatography using n-hexane: ethyl acetate solvent system $(65: 35)$; solid product, M.P. $188-189^{\circ} \mathrm{C}$, yield $78 \%$. ${ }^{1} \mathrm{H}$ NMR (DMSO-d $\left.\mathrm{d}_{6}\right) \delta: 8.27(1 \mathrm{H}, \mathrm{s}), 7.79(1 \mathrm{H}, \mathrm{s})$, 7.58-7.68 $(4 \mathrm{H}, \mathrm{m}), 6.86(1 \mathrm{H}, \mathrm{d}, J=9 \mathrm{~Hz}), 6.06(1 \mathrm{H}, \mathrm{dd}, J=$ $9,3 \mathrm{~Hz}), 3.67(3 \mathrm{H}, \mathrm{s}), 3.48(3 \mathrm{H}, \mathrm{s})$, and $2.75(3 \mathrm{H}, \mathrm{s}) \cdot{ }^{13} \mathrm{C}$ NMR (DMSO-d ${ }_{6}$ ) $\delta$ ppm: $173.86,158.94,153.35,143.18$, $135.35,133.35,132.79,132.52,130.51,128.30,127.77$, 
$127.22,111.94,108.76,107.43,56.55,55.85$, and 13.17; HRMS $(m / z):[\mathrm{M}+\mathrm{H}]^{+}$calcd for $\mathrm{C}_{19} \mathrm{H}_{18} \mathrm{ClN}_{2} \mathrm{O}_{4} 373.0955$, found 373.0954 .

\subsubsection{3-(2-Chlorophenyl)-5-methyl-N-phenylisoxazole-4-} carboxamide (2f). Purified by silica gel column chromatography using n-hexane: ethyl acetate solvent system $(70: 30)$; solid product, M.P. $201-202^{\circ} \mathrm{C}$, yield $69 \% .{ }^{1} \mathrm{H}$ NMR $\left(\mathrm{DMSO}_{-} \mathrm{d}_{6}\right) \delta: 10.14(1 \mathrm{H}, \mathrm{s}), 7.47-7.58(6 \mathrm{H}, \mathrm{m}), 7.30(2 \mathrm{H}, \mathrm{t}$, $J=7.5 \mathrm{~Hz}), 7.07(1 \mathrm{H}, \mathrm{t}, J=7.2 \mathrm{~Hz})$, and $2.66(3 \mathrm{H}, \mathrm{s}) .{ }^{13} \mathrm{C}$ NMR (DMSO-d ${ }_{6}$ ) $\delta$ ppm: 170.10, 160.45, 159.86, 139.13, $132.79,132.25,132.03,130.10,129.19,127.90,127.83$, $124.35,120.27,115.06$, and 12.77. HRMS $(m / z):[\mathrm{M}+\mathrm{H}]^{+}$ calcd for $\mathrm{C}_{17} \mathrm{H}_{14} \mathrm{ClN}_{2} \mathrm{O}_{2}$ 313.0744, found 313.0748.

2.1.8. 3-(2-Chlorophenyl)-5-methyl-N-(3,4,5-trimethoxyphenyl) isoxazole-4-carboxamide (2g). Purified by silica gel column chromatography using n-hexane: ethyl acetate solvent system (70:30); solid product, M.P. $214-215.5^{\circ} \mathrm{C}$, yield $90 \%$; ${ }^{1} \mathrm{H}$ NMR (DMSO-d $\left.\mathrm{d}_{6}\right) \delta: 10.06(1 \mathrm{H}, \mathrm{s}), 7.47-7.60(4 \mathrm{H}, \mathrm{m})$, $6.93(2 \mathrm{H}, \mathrm{s}), 3.71(6 \mathrm{H}, \mathrm{s}), 3.61(3 \mathrm{H}, \mathrm{s})$, and $2.66(3 \mathrm{H}, \mathrm{s})$. ${ }^{13} \mathrm{C}$ NMR (DMSO-d 6 ) $\delta$ ppm: 170.03, 160.42, 159.68, $153.19,135.33,134.31,132.85,132.19,131.99,130.12$, $127.98,127.83,115.07,97.93,60.57,56.21$, and 12.80. HRMS $(m / z):[\mathrm{M}+\mathrm{H}]^{+}$calcd for $\mathrm{C}_{20} \mathrm{H}_{20} \mathrm{ClN}_{2} \mathrm{O}_{5}$ 403.1048, found 403.1055.

\subsection{Biological Methods}

2.2.1. Cell Culture and Cytotoxicity Assay. Hep3B, HeLa, and MCF7 cancer cell lines were cultured in Roswell Park Memorial Institute- (RPMI-) 1640 medium and supplemented with $10 \%$ foetal bovine serum, $1 \% \mathrm{~L}$-glutamine, and $1 \%$ penicillin/streptomycin in a humidified atmosphere with $5 \% \mathrm{CO}_{2}$ at $37^{\circ} \mathrm{C}$. The cells were seeded at $2.6 \times 10^{4}$ cells/well in a 96well plate. After $72 \mathrm{~h}$, the cells were confluent; the medium was changed and cells were incubated with various concentrations $(500,100,50,10$, and $1 \mu \mathrm{g} / \mathrm{ml})$ of the synthesised compounds for $24 \mathrm{~h}$ [14]. Cell viability was assessed with the Cell Tilter $96^{\circledR}$ Aqueous One Solution Cell Proliferation (MTS) assay according to the manufacturer's instructions (Promega Corporation, Madison, WI). Briefly, at the end of the treatment, $20 \mu \mathrm{l}$ of MTS solution per $100 \mu \mathrm{l}$ of medium was added to each well and incubated at $37^{\circ} \mathrm{C}$ for $2 \mathrm{~h}$. The absorbance was measured at $490 \mathrm{~nm}[39,40]$.

2.2.2. Alpha-Fetoprotein (aFP) Analysis. Hep3B cells were cultured in Dulbecco's Modified Eagle Medium (DMEM) with $10 \%$ foetal bovine to examine the level of aFP as a marker of tumour activity. We marked Hep3B cells by labelling their surface with HBsAg (Water et al., 1998). Hep3B cells were incubated with DDW and silica in $10 \mu \mathrm{l} / \mathrm{ml}$ for $24 \mathrm{~h}$. A commercially available enzyme-linked immunosorbent assay (ELISA) kit (R\&D Systems, Inc., Minneapolis, $\mathrm{MN}$, USA) was used to assess the level of aFP in the medium.

2.2.3. Apoptosis and Cell Cycle Analysis. Hep3B cells were trypsinised $(0.05 \%$ trypsin $/ 0.53 \mathrm{mM}$ EDTA $)$, washed, and adjusted to $1 \times 10^{6}$ cells $/ \mathrm{ml}$ (in saline containing $1 \%$ albumin; Biological Industries, Israel) for $10 \mathrm{~min}$ to determine their purity. The cells were fixed with $4 \%$ paraformaldehyde and permeabilised in $0.1 \%$ saponin in phosphate-buffered saline (PBS) for $20 \mathrm{~min}$ at room temperature. They were then stained with an anti-human HBsAg monoclonal antibody (R\&D System) for $30 \mathrm{~min}$ at room temperature. The cells were then incubated with propidium iodide (PI) to stain fragmented DNA and Annexin V conjugated to fluorescein isothiocyanate (FITC) (R\&D systems) to stain phosphatidylserine (PS) according to the manufacturer's instructions. The cells were analysed by flow cytometry (Becton-Dickinson LSR 11, Immunofluorometry Systems, Mountain View, CA, USA). Apoptotic cells were defined as Annexin V $(+) /$ PI (-). Viable cells were defined as Annexin V (-)/PI (-). In each experimental setting, unstained controls, immunoglobulin G (IgG) isotype controls, and FMO controls were used [41].

To analyse the cell cycle, Hep3B was fixed in cold $70 \%$ ethanol for at least $30 \mathrm{~min}$ at $4^{\circ} \mathrm{C}$. After washing two time in PBS, the cells were treated with $50 \mu \mathrm{l}$ RNase $(100 \mu \mathrm{g} / \mathrm{ml})$, stained with $5 \mu \mathrm{l}$ propidium iodide (PI) $(50 \mu \mathrm{g} \mathrm{PI} / 100 \mathrm{ml}$ solution), and analysed with flow cytometry [41].

2.3. Antioxidant Activity. The antioxidant activity was measured for synthesised compounds $\mathbf{2 a - 2 g}$. A $1 \mathrm{mg} / \mathrm{ml}$ solution of each compound was prepared by dissolving $1 \mathrm{mg}$ in $1 \mathrm{ml}$ of methanol; this stock was diluted with methanol to obtain several concentrations $(2,5,10,20,50$, and $100 \mu \mathrm{g} / \mathrm{ml})$. One millilitre of each concentration was mixed with $1 \mathrm{ml}$ of methanol and $1 \mathrm{ml}$ of 2,2-diphenyl-1-picrylhydrazyl (DPPH) solution. The solution was incubated for $30 \mathrm{~min}$ in the dark at room temperature. A blank solution was prepared by replacing the plant fraction with methanol [42]. Trolox was used as a positive control. The absorbance was measured by a UV-Vis spectrophotometer at $517 \mathrm{~nm}$ then compared with the control. The antioxidant activity was calculated with the following equation:

$$
\left.\mathrm{I}(\%)=\left[\mathrm{ABS}_{\text {blank }}-\mathrm{ABS}_{\text {test }}\right] /\left[\mathrm{ABS}_{\text {blank }}\right]\right) \times 100 \%
$$

where I (\%) is the percent antioxidant activity and ABS is the absorbance at $517 \mathrm{~nm}$.

The antioxidant $\mathrm{IC}_{50}$ for each synthesised compounds was calculated using BioDataFit 1.02 (data fit for biologists) [43].

2.4. Statistical Analyses. The antioxidant activity was measured in triplicate for each sample, while the cytotoxic test was measured in duplicate for each sample. The obtained results are presented as the mean \pm standard deviation. Statistical analysis was performed using the GraphPad Prism software version 6.01 (GraphPad Software, San Diego, CA, USA). Three or more groups were compared with one-way analysis of variance (ANOVA) followed by Bonferroni's post hoc test.

\section{Results and Discussion}

3.1. Chemistry. The isoxazole-carboxamide derivatives (2a$\mathbf{2 g}$ ) were synthesised as outlined in Figure 3. The coupling to form the isoxazole-carboxamide compounds $\mathbf{2 a - 2} \mathbf{g}$ was 


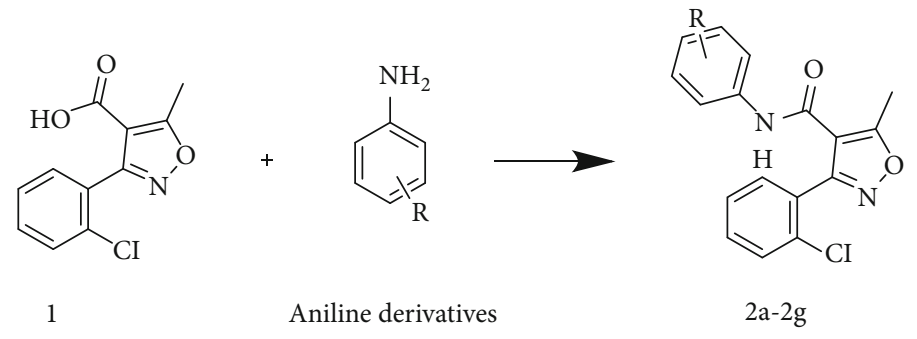

FIGURE 3: 1+ aniline derivatives dissolved in $15 \mathrm{ml} \mathrm{DCM}$, then DMAP and EDC added under nitrogen gaz stir for $24 \mathrm{~h}$.

TABLE 1: $\mathrm{IC}_{50}$ of isoxazole compounds and doxorubicin on different cancer cells (Hep3B, HeLa, and MCF-7).

$$
\text { (l) }
$$

Code

$2 \mathrm{a}$

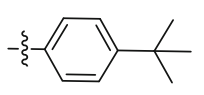

$2 b$

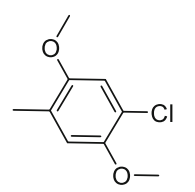

2c

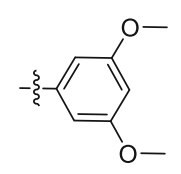

$2 \mathrm{~d}$

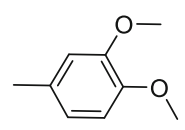

$2 \mathrm{e}$

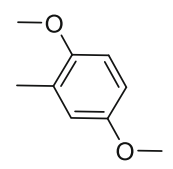

$2 \mathrm{f}$

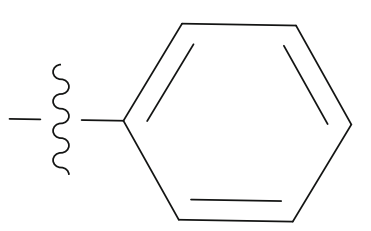

$2 g$

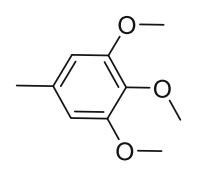

$$
\mathrm{IC}_{50}(\mu \mathrm{g} / \mathrm{ml})
$$

Hep 3B

Hela

MCF

$79.43 \pm 2.34$

$18.62 \pm 0.79$

$39.80 \pm 1.63$

Inactive

$45.70 \pm 1.67$

$85.10 \pm 2.72$

Inactive

Inactive

$75.80 \pm 2.36$

$23.98 \pm 1.83$

$15.48 \pm 0.89$

Inactive

$23.44 \pm 1.99$

$32.35 \pm 3.05$

$63.10 \pm 2.14$

$81.28 \pm 2.23$

Inactive

$98.5 \pm 2.57$

Inactive

Inactive

Inactive

DOX

$1.25 \pm 0.19$

$2.13 \pm 0.07$

$1.55 \pm 0.23$

Note: $P$ value $\leq 0.05$.

afforded by using EDC as an activating agent and DMAP as a covalent nucleophilic catalyst; the active intermediates were reacted with the aniline derivatives [44]. High-resolution mass spectrometry (HRMS) was used to confirm the synthesis of these seven compounds. They were purified by using column chromatography (a 70:30 mixture of $n$-hexa- ne: ethyl acetate solvent). The proton nuclear magnetic resonance $\left({ }^{1} \mathrm{H}-\mathrm{NMR}\right)$ peaks confirmed the synthesis of these compounds. There was one proton in the range of $8.27-$ $10.14 \mathrm{ppm}$ as a singlet peak for the N-H amide of each compound; there were 6-9 protons (depending on whether or not the phenyl was substituted) in the aromatic area and another 


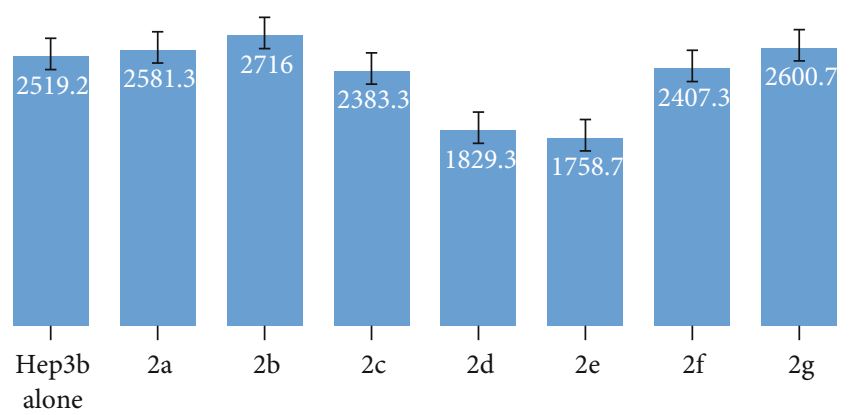

Figure 4: Cell proliferations of synthesized compound $\mathbf{2 a}-\mathbf{2} \mathbf{g}$ and untreated cells (control).

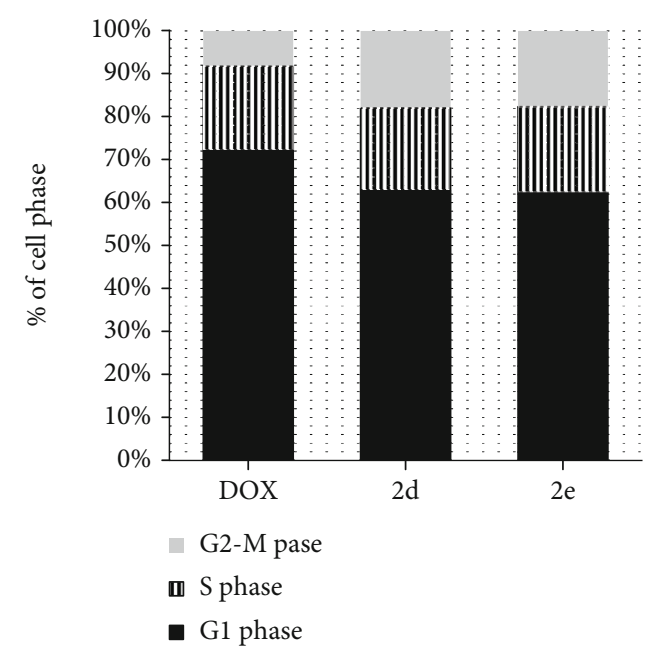

FIgure 5: Cell cycle analysis of Hep3B cells after treatment with compound 2e, 2d, and DOX control.

3 protons around $2.66 \mathrm{ppm}$ as a singlet peak, which refers to the methyl group on the isoxazole ring. The ${ }^{13} \mathrm{C}$-NMR spectrum showed a $C$ signal of a carbonyl group around $170 \mathrm{ppm}$; a signal at $12-13 \mathrm{ppm}$ indicated an aliphatic carbon methyl.

\subsection{Biological Evaluations}

3.2.1. Cytotoxic Evaluation of the Compounds 2a-2g. Table 1 shows the cytotoxic effect of compounds $2 \mathbf{a}-\mathbf{2 g}$ on MCF-7, HeLa, and Hep3B cancer cell lines. Compounds 2d and 2e showed the greatest anticancer activity against Hep3B cells, while the rest of the compounds had a high $\mathrm{IC}_{50}$; a compound with an $\mathrm{IC}_{50}>100 \mu \mathrm{g} / \mathrm{ml}$ is listed as "inactive" in Table 1 . Compound 2d was the most potent against HeLa cells $\left(\mathrm{IC}_{50}=18.62 \mu \mathrm{g} / \mathrm{ml}\right)$, and compound $2 \mathrm{a}$ was also active against HeLa cells $\left(\mathrm{IC}_{50}=39.80 \mu \mathrm{g} / \mathrm{ml}\right)$. However, the other compounds showed weak anticancer activity against MCF-7 cells $\left(\mathrm{IC}_{50}\right.$ values from 63.10 to $\left.588.80 \mu \mathrm{g} / \mathrm{ml}\right)$.

3.2.2. Alpha-Fetoprotein Results. According to cytotoxicity results and because $\mathbf{2} \mathbf{d}$ and $\mathbf{2 e}$ were the most active against Hep3B cells, we evaluated the levels of aFP secreted into the medium to examine the inhibitory effects of the synthesised compound on cell proliferation. Compounds $2 \mathbf{d}$ and $2 \mathrm{e}$

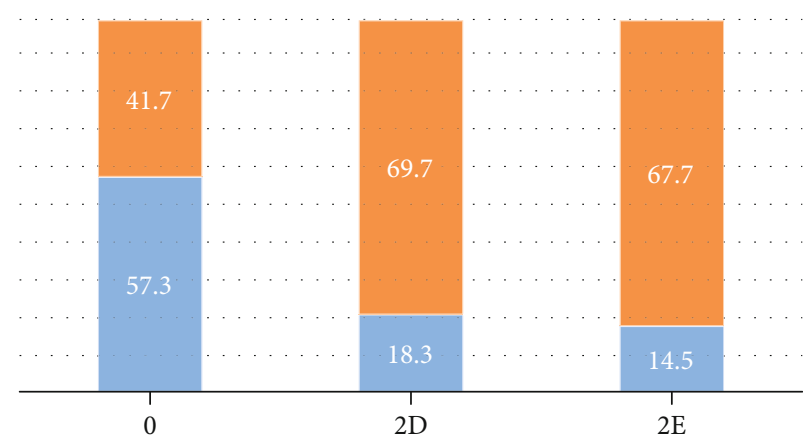

I. Annexin $\mathrm{V}+/ \mathrm{PI}-$

- Annexin V+/PI+

FIgURe 6: Apoptosis vs. necrosis for compounds 2d and 2e.

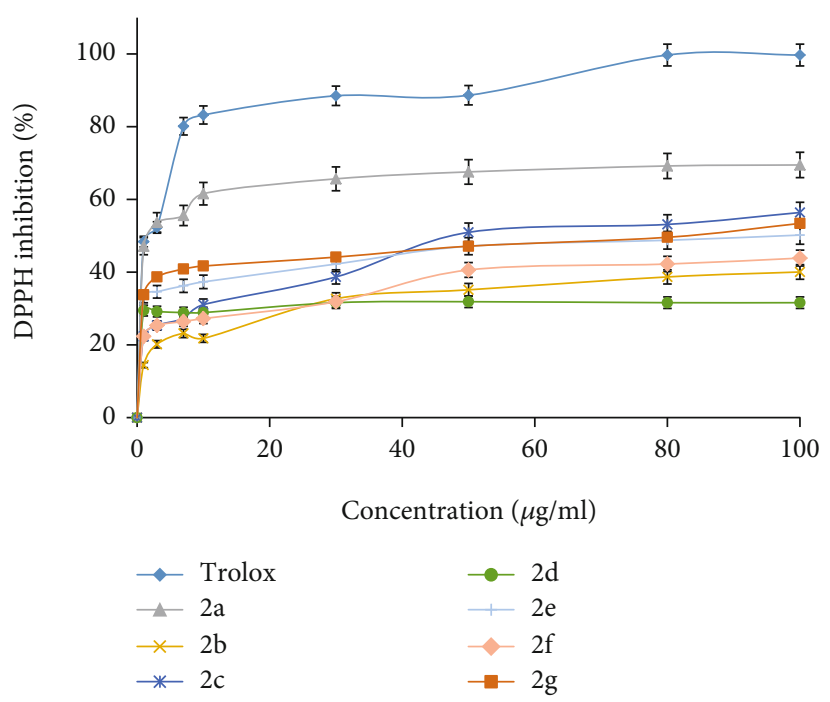

FIgURE 7: The DPPH inhibition percentage of synthesized compounds and Trolox.

reduced Hep3B secretion of aFP to $1829.33 \pm 65.91$ and $1758.66 \pm 54.04 \mathrm{ng} / \mathrm{ml}$, respectively, compared with 2519.17 $\pm 198.05 \mathrm{ng} / \mathrm{ml}$ in untreated cells. Compounds $\mathbf{2 c}$ and $\mathbf{2 f}$ did not reduce aFP secretion $(2383.33$ and $2407.33 \mathrm{ng} / \mathrm{ml}$, respectively) compared with $\mathbf{2 d}$ and $\mathbf{2 e}$ (Figure 4 ). Overall, 2d and 2e have anticancer activity against Hep3B cells (Figure 4).

3.2.3. 2d and 2e Inhibited DNA Cell Cycle of Hep3B Cells. Because $2 \mathbf{d}$ and $2 \mathbf{e}$ were cytotoxic to Hep3B cells, they were assessed to determine whether they disturbed the cell cycle. Doxorubicin (DOX) was used to a positive control to induce cell cycle progression. The data in Figure 5 show a similar proportion of cells in the G1 phase following treatment with compounds $2 \mathrm{~d}$ or $2 \mathrm{e}$ or DOX. Compounds $\mathbf{2 d}$ and $2 \mathrm{e}$ also showed similar behaviour to DOX in reducing the percent of cells in the $S$ as well as the G2/M phase $(P<0.05)$. Indeed, $2 \mathbf{d}$ and $2 \mathbf{e}$ reduced the proportion of cells in the G2/M phase up to 3.6 -fold. These data indicate that $\mathbf{2 d}$ and $\mathbf{2 e}$ markedly delay mitosis, suggesting they have potential anticancer characteristics. 
3.2.4. Apoptosis vs. Necrosis Test. We next determined whether 2d and 2e induced apoptosis (programmed cell death) and necrosis. Cells undergoing apoptosis have their PS phospholipids translocated from the inner face of the plasma membrane to the cell surface. Therefore, apoptotic cells can be identified by the presence of PS on the cell surface using Annexin V-FITC staining and flow cytometric analysis. Cells were also stained with PI, which can enter the cell only when the plasma membrane is damaged. Apoptosis was evaluated as Annexin V (+)/PI (-); this population was distinguished from late apoptotic and necrotic cells, which were considered Annexin V (+)/PI (-). Untreated Hep3B cells showed $57.33 \% \pm 7.5 \%$ apoptotic cells; treatment with $2 \mathrm{~d}$ and $2 \mathrm{e}$ reduced apoptosis to $14.53 \% \pm 3.4 \%$ and $18.26 \% \pm 2.1 \%$, respectively (Figure 6 ). Treatment with 2d and 2e increased the Annexin V (+)/PI (+) fraction (apoptotic/necrotic cells) to $67.66 \% \pm 4.9 \%$ and $69.67 \% \pm 3.3 \%$, respectively, compared with $41.66 \% \pm 1.52 \%$ in untreated cells. Our data strongly suggest that compounds $\mathbf{2 d}$ and $\mathbf{2 e}$ have anticancer properties through increasing the necrotic activity of hepatocellular cancer cells and thus accelerating their death.

3.3. Antioxidant Evaluation. We estimated the antioxidant activity of compounds $\mathbf{2 a - 2} \mathbf{g}$ using an in vitro DPPH assay; we compared the results to the well-known antioxidant compound Trolox. We tested a range of concentrations to determine the $\mathrm{IC}_{50}$ of each compound. The most active compound was $\mathbf{2 a}$, with an $\mathrm{IC}_{50} 7.8 \pm 1.21 \mu \mathrm{g} / \mathrm{ml}$, while $\mathbf{2 c}, \mathbf{2 e}$, and $\mathbf{2 g}$ had an $\mathrm{IC}_{50}$ of $56.1,67.6$, and $51.2 \mu \mathrm{g} / \mathrm{ml}$, respectively. For comparison, the Trolox $\mathrm{IC}_{50}$ was $2.75 \mu \mathrm{g} / \mathrm{ml}$. Compounds $\mathbf{2 b}, \mathbf{2 d}$, and $\mathbf{2 f}$ had very weak antioxidant activity (Figure 7 ).

One of the main causes of diseases such as cancer, stroke, inflammatory bowel disease, atherosclerosis, and cirrhosis is thought to be oxidative stress, which is caused by free radicals [45]. The genomic integrity of the cell is maintained by a balance between the levels of prooxidants and antioxidants. The host's immunity is modulated if this balance is destructed and will affect the normal cellular signaling pathways leading to uncontrolled proliferation of the cells, ending with cancer and macrophage polarisation leading to the formation of atherogenic plaques $[46,47]$. In these conditions, particularly in the tumour microenvironment, there is higher basal oxidative stress that takes advantage of the upregulated antioxidant system [23].

\section{Conclusion}

The synthesised compounds showed moderate to high activity against Hep3B, HeLa, and MCF-7 cancer cell lines compared with the commonly used anticancer drug DOX. Of note, compounds $\mathbf{2 d}$ and $\mathbf{2 e}$ showed superiority compared with the other synthesised compounds. Moreover, compound 2a showed great potential to ameliorate oxidative stress compared with the standard Trolox, followed by compounds 2g, 2c, and 2e. Future plans could involve docking and synthesis of additional analogues of this core structure to examine the structure-activity relationship.

\section{Data Availability}

The datasets used and/or analysed during the current study available from the corresponding author on reasonable request.

\section{Conflicts of Interest}

The authors declare that they have no competing interests.

\section{Authors' Contributions}

A.E. and M.H. conceived and designed the current study. A.E., M.H., J.A., A.J., S.Q., I.A., A.S., R.Z., O.H., S.H., and A.M. analyzed the data obtained. This paper was written by A.E., M.H., and J.A. and drafted by all authors. All authors read and approved the final manuscript.

\section{Acknowledgments}

The authors would like to thank An-Najah National University for funding this study (grant number ANNU-1920Sc014) and the Dean of Scientific Research, Gazi University, and Anadolu University for their support in chemical analysis.

\section{References}

[1] R. Sekhon and N. Bhatla, "Gynecological cancer update," Asian Journal of Oncology, vol. 2, p. 61, 2016.

[2] J. Didkowska, U. Wojciechowska, M. Mańczuk, and J. Łobaszewski, "Lung cancer epidemiology: contemporary and future challenges worldwide," Annals of Translational Medicine, vol. 4, no. 8, p. 150, 2016.

[3] M. Hawash, "Highlights on specific biological targets; cyclindependent kinases, epidermal growth factor receptors, Ras protein, and cancer stem cells in anticancer drug development," Drug Research, vol. 69, no. 9, pp. 471-478, 2019.

[4] K. O. M. Almohammadawi, H. S. Q. Alhilfi, and A. S. H. Alshewered, "Epidemiological data of 1418 cancer cases of inpatient in Al-Sadder Teaching Hospital, Misan Province from 2011-2018 (Surveillance study)," Medical Science, vol. 22, pp. 455-461, 2018.

[5] J. E. Bennett, G. A. Stevens, C. D. Mathers et al., "2030: Worldwide trends in non-communicable disease mortality and progress towards sustainable development goal target 3.4," The Lancet, vol. 392, pp. 1072-1088, 2018.

[6] S. M. Abu Bakr, S. S. Abd El-Karim, M. M. Said, and M. M. Youns, "Synthesis and anticancer evaluation of novel isoxazole/pyrazole derivatives," Research on Chemical Intermediates, vol. 42, no. 2, pp. 1387-1399, 2016.

[7] J. Ferlay, M. Colombet, I. Soerjomataram et al., "Estimating the global cancer incidence and mortality in 2018: GLOBOCAN sources and methods," International Journal of Cancer, vol. 144, no. 8, pp. 1941-1953, 2019.

[8] Y.-H. Chu, S.-L. Tzeng, C.-W. Lin, M.-H. Chien, M.-K. Chen, and S.-F. Yang, "Impacts of microRNA gene polymorphisms on the susceptibility of environmental factors leading to carcinogenesis in oral cancer," PLoS One, vol. 7, no. 6, article e39777, 2012. 
[9] M. T. E. Puts, B. Tapscott, M. Fitch et al., "A systematic review of factors influencing older adults' decision to accept or decline cancer treatment," Cancer Treatment Reviews, vol. 41, no. 2, pp. 197-215, 2015.

[10] C.-Y. Huang, D.-T. Ju, C.-F. Chang, P. M. Reddy, and B. K. Velmurugan, "A review on the effects of current chemotherapy drugs and natural agents in treating non-small cell lung cancer," BioMedicine, vol. 7, no. 4, pp. 23-23, 2017.

[11] M. Arruebo, N. Vilaboa, B. Sáez-Gutierrez et al., "Assessment of the evolution of cancer treatment therapies," Cancers, vol. 3, no. 3, pp. 3279-3330, 2011.

[12] R. Oun, Y. E. Moussa, and N. J. Wheate, "The side effects of platinum-based chemotherapy drugs: a review for chemists," Dalton Transactions, vol. 47, no. 19, pp. 6645-6653, 2018.

[13] M. S. Aslam, S. Naveed, A. Ahmed, Z. Abbas, I. Gull, and M. A. Athar, "Side effects of chemotherapy in cancer patients and evaluation of patients opinion about starvation based differential chemotherapy," Journal of Cancer Therapy, vol. 5, no. 8, pp. 817-822, 2014.

[14] N. A. Jaradat, S. Al-lahham, A. N. Zaid et al., "Carlina curetum plant phytoconstituents, enzymes inhibitory and cytotoxic activity on cervical epithelial carcinoma and colon cancer cell lines," European Journal of Integrative Medicine, vol. 30, article 100933, 2019.

[15] M. M. Hawash and S. N. Baytas, "Antiproliferative activities of some biologically important scaffolds," FABAD Journal of Pharmaceutical Sciences, vol. 43, pp. 59-77, 2018.

[16] P. Nathan, M. Zweifel, A. R. Padhani et al., "Phase I trial of combretastatin A4 phosphate (CA4P) in combination with bevacizumab in patients with advanced cancer," Clinical Cancer Research, vol. 18, no. 12, pp. 3428-3439, 2012.

[17] E. Abma, S. Daminet, P. Smets, Y. Ni, and H. De Rooster, "Combretastatin A4-phosphate and its potential in veterinary oncology: a review," Veterinary and Comparative Oncology, vol. 15, no. 1, pp. 184-193, 2017.

[18] S. Shahinshavali, R. Sreenivasulu, V. Guttikonda, D. Kolli, and M. Rao, "Synthesis and anticancer activity of amide derivatives of 1,2-isoxazole combined 1, 2, 4-thiadiazole," Russian Journal of General Chemistry, vol. 89, no. 2, pp. 324-329, 2019.

[19] J.-P. Yong, C.-Z. Lu, and X. Wu, "Potential anticancer agents. I. Synthesis of isoxazole moiety containing quinazoline derivatives and preliminarily in vitro anticancer activity," Anti-Cancer Agents in Medicinal Chemistry, vol. 15, no. 1, pp. 131-136, 2014.

[20] R. N. Kumar, G. J. Dev, N. Ravikumar et al., "Synthesis of novel triazole/isoxazole functionalized 7-(trifluoromethyl)pyrido[2,3-_ d_ ] pyrimidine derivatives as promising anticancer and antibacterial agents," Bioorganic \& Medicinal Chemistry Letters, vol. 26, no. 12, pp. 2927-2930, 2016.

[21] C. A. Kumar, B. Veeresh, K. Ramesha et al., "Antidiabetic studies of 1-benzhydryl-piperazine sulfonamide and carboxamide derivatives," Journal of Applied Chemistry, vol. 6, 240 pages, 2017.

[22] V. K. Govindappa, J. Prabhashankar, B. B. A. Khatoon, M. B. Ningappa, and A. K. Kariyappa, "Synthesis of 3, 5-diaryl-isoxazole-4-carbonitriles and their efficacy as antimicrobial agents," Pharmacy Chemica, vol. 4, pp. 2283-2287, 2012.

[23] A. Sysak and B. Obmińska-Mrukowicz, "Isoxazole ring as a useful scaffold in a search for new therapeutic agents," European Journal of Medicinal Chemistry, vol. 137, pp. 292-309, 2017.
[24] S. R. Pedada, N. S. Yarla, P. J. Tambade et al., "Synthesis of new secretory phospholipase $\mathrm{A}_{2}$-inhibitory indole containing isoxazole derivatives as anti-inflammatory and anticancer agents," European Journal of Medicinal Chemistry, vol. 112, pp. 289-297, 2016.

[25] J. Zhu, J. Mo, H. Z. Lin, Y. Chen, and H. P. Sun, “The recent progress of isoxazole in medicinal chemistry," Bioorganic \& Medicinal Chemistry, vol. 26, no. 12, pp. 3065-3075, 2018.

[26] P. A. Brough, W. Aherne, X. Barril et al., “4, 5-Diarylisoxazole Hsp 90 chaperone inhibitors: potential therapeutic agents for the treatment of cancer," Journal of Medicinal Chemistry, vol. 51, no. 2, pp. 196-218, 2008.

[27] B. Çalışkan, E. Sinoplu, K. İbiş, E. Akhan Güzelcan, R. Çetin Atalay, and E. Banoglu, "Synthesis and cellular bioactivities of novel isoxazole derivatives incorporating an arylpiperazine moiety as anticancer agents," Journal of Enzyme Inhibition and Medicinal Chemistry, vol. 33, no. 1, pp. 1352-1361, 2018.

[28] X. Xue, Y. Zhang, C. Wang et al., "Benzoxazinone-containing 3,5-dimethylisoxazole derivatives as BET bromodomain inhibitors for treatment of castration-resistant prostate cancer," European Journal of Medicinal Chemistry, vol. 152, pp. 542-559, 2018.

[29] A. Kamal, V. S. Reddy, A. B. Shaik et al., "Synthesis of (Z)-(arylamino)-pyrazolyl/isoxazolyl-2-propenones as tubulin targeting anticancer agents and apoptotic inducers," Organic of Biomolecular Chemistry, vol. 13, no. 11, pp. 3416-3431, 2015.

[30] F. Solano, S. Briganti, M. Picardo, and G. Ghanem, "Hypopigmenting agents: an updated review on biological, chemical and clinical aspects," Pigment Cell Research, vol. 19, no. 6, pp. 550571,2006

[31] A. Detsi, D. Bouloumbasi, K. C. Prousis et al., "Design and synthesis of novel quinolinone-3-aminoamides and their $\alpha$-lipoic acid adducts as antioxidant and anti-inflammatory agents," Journal of Medicinal Chemistry, vol. 50, no. 10, pp. 24502458, 2007.

[32] H. Seiss, "Strategies of antioxidant defence," European Journal of Biochemistry, vol. 215, pp. 213-219, 1993.

[33] J. F. Weiss and M. R. Landauer, "Radioprotection by antioxidants," Annals of the New York Academy of Sciences, vol. 899, pp. 44-60, 2000.

[34] A. Abu-Hashem, M. El-Shehry, and F. Badria, "Design and synthesis of novel thiophenecarbohydrazide, thienopyrazole and thienopyrimidine derivatives as antioxidant and antitumor agents," Acta Pharmaceutica, vol. 60, no. 3, pp. 311-323, 2010.

[35] A. Kumar, R. A. Maurya, S. Sharma, M. Kumar, and G. Bhatia, "Synthesis and biological evaluation of N-aryl-1,4-dihydropyridines as novel antidyslipidemic and antioxidant agents," European Journal of Medicinal Chemistry, vol. 45, no. 2, pp. 501-509, 2010.

[36] W.-S. Hong, H.-Y. Jung, S.-K. Yang et al., “The antioxidant effect of rebamipide on oxygen free radical production by $H$. pylori -activated human neutrophils: in comparison with $\mathrm{N}$ acetylcysteine, ascorbic acid and glutathione," Pharmacological Research, vol. 44, no. 4, pp. 293-297, 2001.

[37] R. van den Berg, G. R. Haenen, H. van den Berg, and A. Bast, "Applicability of an improved Trolox equivalent antioxidant capacity (TEAC) assay for evaluation of antioxidant capacity measurements of mixtures," Food Chemistry, vol. 66, no. 4, pp. 511-517, 1999.

[38] M. Hawash, A. M. Eid, N. Jaradat et al., "Synthesis and biological evaluation of benzodioxole derivatives as potential 
anticancer and antioxidant agents," Heterocyclic Communications, vol. 26, no. 1, pp. 157-167, 2020.

[39] N. Jaradat, S. Al-Lahham, M. N. Abualhasan et al., "Chemical constituents, antioxidant, cyclooxygenase inhibitor, and cytotoxic activities of Teucrium pruinosum boiss. Essential oil," BioMed Research International, vol. 2018, Article ID 4034689, 9 pages, 2018.

[40] M. Hawash, N. Jaradat, S. Hameedi, and A. Mousa, "Design, synthesis and biological evaluation of novel benzodioxole derivatives as COX inhibitors and cytotoxic agents," BMC Chemistry, vol. 14, pp. 1-9, 2020.

[41] J. Waters, C. Bailey, C. Love, and H. Thomas, "A study of the antigenicity and immunogenicity of a new hepatitis $\mathrm{B}$ vaccine using a panel of monoclonal antibodies," Journal of Medical Virology, vol. 54, no. 1, pp. 1-6, 1998.

[42] N. Jaradat, M. Qneibi, M. Hawash et al., "Chemical composition, antioxidant, antiobesity, and antidiabetic effects of Helichrysum sanguineum (L.) Kostel. From Palestine," Arabian Journal for Science and Engineering, vol. 46, no. 1, pp. 41-51, 2021.

[43] A. Bouyahya, N. El Moussaoui, J. Abrini, Y. Bakri, and N. Dakka, "In vitro Antibacterial Activity of Organic extracts from North-West Moroccan Medicinal Plant Myrtus communis (L.)," Biotechnology Journal International, vol. 16, no. 4, pp. 1-9, 2016.

[44] M. Biava, C. Battilocchio, G. Poce et al., "Enhancing the pharmacodynamic profile of a class of selective COX-2 inhibiting nitric oxide donors," Bioorganic \& Medicinal Chemistry, vol. 22, no. 2, pp. 772-786, 2014.

[45] S. Khogta, V. Addepalli, H. S. Buttar, and G. Kaur, "Potentials of Phytopharmaceuticals for Treating Microbiological and Oxidative Stress-Induced Type 2 Diabetes," in Oxidative Stress in Microbial Diseases, pp. 489-509, Springer, 2019.

[46] K. J. Amit, N. K. Mehra, and N. K. Swarnakar, "Role of antioxidants for the treatment of cardiovascular diseases: challenges and opportunities," Current Pharmaceutical Design, vol. 21, no. 30, pp. 4441-4455, 2015.

[47] M. Khosravi, A. Poursaleh, G. Ghasempour, S. Farhad, and M. Najafi, "The effects of oxidative stress on the development of atherosclerosis," Biological Chemistry, vol. 400, no. 6, pp. 711-732, 2019. 